\title{
KADAR AIR, PIPERIN DAN MINYAK ATSIRI LADA PRODUK UKM SAMBOJA, UKM BONTANG DAN DI PASARAN SAMARINDA
}

\author{
MOISTURE CONTENT, PIPERINE AND ESSENTIAL OILS OF \\ PEPPER PRODUCED BY SME SAMBOJA, SME BONTANG AND THOSE \\ CIRCULATED IN SAMARINDA MARKET
}

\author{
Eldha Sampepana, Adhitya Rinaldi, Titik Nurwidayati, Suroto Hadi Saputra \\ Balai Riset dan Standardisasi Industri Samarinda \\ Jl. MT. Haryono/Banggeris No. 1 Samarinda \\ Email : dha spana@yahoo.com
}

Diterima : 30-11-2020

Direvisi : 11-12-2020

Disetujui : 23-12-2020

\begin{abstract}
ABSTRAK
Luas perkebunan lada Provinsi Kalimantan Timur sebesar 8.921 ribu ha dan memiliki aroma lada yang menyengat serta pedas. Lada Kalimantan Timur belum dapat bersaing secara nasional maupun internasional karena mutu yang dihasilkan masih rendah sehingga dilakukan penelitian dengan tujuan mengkarakteristik kadar air, kadar piperin dan kadar minyak atsiri lada putih bubuk dan lada hitam bubuk produksi UKM Samboja dan UKM Bontang serta membandingkannya produk lada yang beredar di pasaran Samarinda. Metode sampling yang digunakan adalah mengambil sampel lada dari 3 lokasi yang berbeda yaitu UKM Samboja, UKM Bontang dan sampel lada yang beredar di Pasaran Samarinda (lada putih bubuk: kode C, D, E) dan lada hitam bubuk (kode X, Y). Hasil analisa lada dari ketiga lokasi pengambilan sampel secara berturut-turut adalah produk lada putih bubuk dengan parameter kadar air: (10,31\%; 9,13\%; 7,85\%; 9,88\%; 8,08\%), kadar piperin: $(4,62 \% ; 5,16 \% ; 5,58 \% ; 6,11 \% ; 6,05 \%)$. Minyak atsiri $(2,34 \% ; 3,49 \% ; 4,17 \% .4,11 \% ; 3,57 \%)$. Hasil lada hitam bubuk dengan parameter kadar air: $(10,98 \% ; 7,57 \% ; 9,18 \% ; 7,34 \%)$, kadar piperin: $(5,28 \% ; 5,90 \% ; 6,36 \% ; 6,63 \%)$ dan minyak atsiri: $(3,17 \% ; 3,53 \% ; 4,46 \% ; 4,37 \%)$. Hasil analisa lada dari ketiga parameter tersebut memenuhi standar mutu (SNI 01-3717-1995, SNI 01-3179-1992, SNI 0004:2013, SNI 005:2013) dan standar mutu internasional (ASTA, ESA, IPC, ISO).
\end{abstract}

Kata Kunci: kadar air, lada hitam bubuk, lada putih bubuk, minyak atsiri, piperin

\section{ABSTRACT}

The area of East Kalimantan province pepper plantations of 8,921 thousand ha and has a pungent and spicy pepper aroma. East Kalimantan pepper has not been able to compete nationally or internationally because the resulting quality is still low. Based on that phenomena, this research is carried out on the aim of characterizing the water content, the piperine content and the essential oil content of white pepper powder and black pepper powder produced by SME Samboja and SME Bontang and comparing it with the pepper products circulating in samarinda market. The sampling method conducted by taking pepper samples from 3 different locations namely SME Samboja, SME Bontang and pepper samples circulating in Samarinda Market (white pepper powder: code $C, D, E$ ) and black pepper powder (code $X, Y$ ). Pepper analysis results from the three sampling locations in a row were powdered white pepper products with water content parameters: $(10.31 \% ; 9.13 \% ; 7.85 \% ; 9.88 \% ; 8.08 \%)$, piperine content: (4.62\%; 5.16\%; 5.58\%; 6.11\%; 6.05\%), and Essential oils (2.34\%; 3.49\%; 4.17\%. 4.11\%; 3.57\%). The results of powdered black pepper with water content parameters: $(10.98 \% ; 7.57 \% ; 9.18 \%$; 7.34\%), piperine content: (5.28\%; 5.90\%; 6.36\%; 6.63\%) and essential oils: (3.17\%; 3.53\%; 4.46\%; $4.37 \%$ ). The pepper analysis results from these three parameters meet quality standards (SNI 01-3717- 
1995, SNI 01-3179-1992, SNI 0004:2013, SNI 005:2013) and international quality standards (ASTA, ESA, IPC, ISO).

Keywords: moisture content, black powder pepper, white powder pepper, essential oil, piperin,

\section{PENDAHULUAN}

T ndonesia merupakan negara eksportir lada terbesar ke tiga di dunia setelah Vietnam dan Brazil dengan nilai USD 116,08 Juta (8,66\%) dimana Lampung merupakan daerah pengekspor lada terbesar di Indonesia dengan nilai USD 43,33 juta (dengan pangsa pasar 29,41 persen), diikuti oleh daerah Bangka Belitung USD 36,52 juta (24,78 persen), Jawa Timur USD 18,12 juta (12,30 persen), Sulawesi Selatan USD 16,68 juta (11,32 persen), DKI Jakarta USD 16,58 juta (11,25 persen), serta Kalimantan Barat USD 6,29 juta (4,27 persen) (Kemendag, 2019).

Indoensia memiliki luas area 180,90 ribu ha dan produksi sebesar 85,30 ribu ton per tahun produksi 85,30 ribu ton per tahun dan masih diproduksi oleh perkebunan rakyat (BPS, 2019). Daerah Kalimantan Timur memiliki luas perkebunan lada sebesar 8.921 ribu ha dengan produksi 5.799 ribu ton/tahun (Dinas Perkebunanan Provinsi Kaltim, 2019).). Lada produk Kalimantan memiliki mutu yang masih rendah sehingga tidak dapat bersaing dengan produk lada yang ada di Indonesia dan bahkan kuar negeri.

Salah satu industri rumah tangga di daerah Kalimantan Timur terdapat 2 Usaha Kecil Menengah (UKM) lada yang terletak di daerah Kecamatan Samboja Kabupaten Kutai Kartanegara dan Kota Bontang. UKM ini dalam memproduksi lada masih sebatas permintaan konsumen dalam kecamatan dan daerah lain di Kalimantan Timur. Produk lada yang dihasilkan oleh UKM tersebut belum mengetahui hasil analisa mutu produk lada yang mereka hasilkan sehingga dilakukanlah penelitian dengan tujuan untuk mengkarakteristik analisa mutu lada berupa kadar air, kadar piperin dan kadar minyak atsiri.

Beberapa penelitian telah dilakukan seperti Rostiana et al. (2018) dalam penelitiannya menggungkapkan bahwa lada putih dan lada Hitam di Kalimantan Timur untuk daerah Kabupaten Kutai Kartanegara yaitu daerah Loa Janan dan daerah Muara Badak memiliki keunggulan yang khas yaitu memiliki aroma dan rasa pedas yang kas dan memiliki kandungan oleoresin dan piperin.

Lada juga mengandung senyawa fenoloik, flavonoid, tanin, protein, antrakuinon, karbohidrat dan alkaloid melalui proses maserisasi dengan pelarut etanol dan metanol (Kadam et al., 2013). Sedangkan melalui proses sokletasi terdapat $14,6 \%$ senyawa alkaloid, $81,2 \%$ senyawa flavonoid dan 17\% senyawa tanin (Asha et al., 2014). Selain itu juga lada mengandung polifenol tinggi (Abdallah, 2018), memiliki daya hambat terhadap bakteri Stapilococcus aureus (Pundir dan Jain, 2010; Al-Shahwany, 2014).

P. nigrum Piperin memiliki empat isomer viz; piperin, isopiperin, chavicine dan isochavicine. Piperin, pipene, piperamide dan piperamine ditemukan bahwa dapat memiliki aktivitas farmakologi (Ahmad et al., 2012); antioksidan (Nahak \& Sahu, 2011). Menurut Depkes (2010) bahwa "felandren, dipenten, kariopilen, entoksilen, limonene merupakan komponen senyawa alkaloid dan minyak atsiri pada buah lada hitam. Loo (1987) juga menyatakan bahwa lada hitam mengandung senyawa alkaloid, piperin, kavisin, metil pirolin, minyak atsiri, lemak, pati dan serat kasar

Vasavirama dan Upender (2014) mengungkapkan bahwa piperin atau $(E, E)-1-[5-(1,3-$ benzodioksol-5-il)-1-okso-2,4-pentadienil] piperidin dengan rumus kimia $\left(\mathrm{C}_{17} \mathrm{H}_{19} \mathrm{NO}_{3}\right)$ memiliki bentuk Kristal berwarna putih kekuningan yang larut etanol, eter dan tidak larut dalam air. Menurut Kolhe et al. (2011), lada banyak digunakan dalam berbagai aspek seperti dibidang pangan sebagai penyedap rasa, bidang farmasi dan kesehatan sebagai antimalarial, antiflamasi, sebagai bahan penurun deman, sebagai bahan penurun obesitas, sebagai bahan 
penetral racun bias ular, epilepsi dan sebagai penyerapan vitamin. tikus Sabina et al. (2013) menggunakan lada sebagai antipiretik. Kumar et al. (2014) juga menggunakan lada sebagai antimikroba, sebagai antioksidan (Gorgani et al., 2017; Dwivedi et al., 2016), sebagai anti hipertensi (Risfaheri, 2012), sebagai antikanker (Gorgani et al., 2017) dan sebagai antibakteri (Zarai et al., 2013).

\section{METODE PENELITIAN}

\section{Bahan dan Alat yang digunakan}

Bahan yang digunakan terdiri dari etanol $\left(\mathrm{C}_{2} \mathrm{H}_{5} \mathrm{OH}\right) 96 \%$ merek Merck, alumunium foil, vaselin, aquades, Lada bubuk putih dan lada bubuk hitam produksi UKM di Samboja Kabupaten Kutai Kartanegara, Lada bubuk putih dan lada bubuk hitam produksi UKM di Kota Bontang dan 4 jenis produk lada bubuk putih dan lada bubuk hitam yang ada di pasaran Samarinda. Sedangkan alat yang digunakan terdiri dari neraca analitik, oven (Mermet) rotovapor (Buchi), heating mantel (Labintech), alat pendingin, heating mantel (Merek: Labentek), seperangkat alat destilasi dari kaca (pirex), Spektrofotometer UV-Vis (merek: Lovibon SpectroDtract dan Shimadzu UV 2600), gelas, piala (pirex), erlenmayer (pirex), corong pisah (pirex), corong (pirex), gelas ukur(pirex), pipiet volumetric (pirex), miropipet 10 $\mu \mathrm{l}$ (Vitlab).

\section{Metode}

Jenis lada yang digunakan dalam kegiatan penelitian ini terdiri dari 2 jenis yaitu lada putih bubuk dan lada hitam bubuk. Lada putih bubuk terdiri dari 5 contoh dalam kemasan botol tersegel yaitu lada putih bubuk dari UKM di Samboja Kabupaten Kutai Kartanegara (A), lada putih bubuk dari UKM di Kota Bontang (B), lada putih bubuk di pasaran Samarinda yaitu 3 jenis merek : C, D dan E. Sedangkan lada hitam bubuk terdiri dari 4 contoh dalam kemasan botol tersegel yaitu lada hitam bubuk dari UKM di Samboja Kabupaten Kutai Kartanegara (R), lada hitam bubuk di produksi UKM di Kota Bontang (S) dan lada hitam bubuk di pasaran Samarinda yaitu 2 jenis merek : X dan Y. Sampel lada putih bubuk dan lada bubuk hitam dianalisa untuk parameter kadar air mengacu pada SNI 01-2891-19 (BSN, 1992). kadar piperin dan kadar minyak atsiri dengan menggunakan metode uji lada sesuai standar uji lada yaitu : SNI 0004:2013 (BSN, 2013).

\section{HASIL DAN PEMBAHASAN}

\section{Kadar Air Lada putih bubuk, Lada hitam bubuk dari UKM di Kalimantan Timur dan Lada di Pasaran Samarinda}

Hasil analisa kadar air lada bubuk putih dan lada bubuk hitam dari UKM di Kalimantan Timur dan di Pasaran seperti pada Gambar 1. Gambar 1 menunjukkan bahwa kadar air lada putih bubuk berkisar 7,85\% - 10,31\% dan lada hitam bubuk 7,34\% sampai 10,98\%. Lada putih bubuk dari pasaran (C) memiliki kandungan kadar air lebih kecil dibandingkan dengan produk lada putih dari pasaran di Samarinda (kode D, E) dan pada UKM Samboja serta UKM bontang. Lada hitam bubuk dengan kode sampel $\mathrm{S}$ lebih kering dibandingkan sampel $\mathrm{Y}, \mathrm{X}$ dan R. Kadar air lada putih bubuk pada Gambar 1 memenuhi standar mutu lada putih bubuk yang dipersyaratkan oleh SNI 01-3717-1995 (BSN, 1995) yaitu maksimal 12\% (b/b) dan standar lada putih SNI 0004 : 2013 maksimal 13,0 \% untuk mutu I (BSN, 2013). Kadar air lada hitam bubuk pada Gambar 1 juga memenuhi standar mutu lada hitam bubuk SNI 01-3179-1992 yaitu maksimal 12\% (BSN, 1992). Kadar yang dipersyaratkan untuk mutu I yaitu max 13\% (BSN, 2013).

Kadar air yang diperoleh untuk semua sampel lada sangat dipengaruhi oleh waktu, suhu dan cara pengeringan dan cara penyimpanan di lokasi produksi dan tempat penyimpanan produk lada UKM dan yang lada yang ada di pasaran Samarinda. 

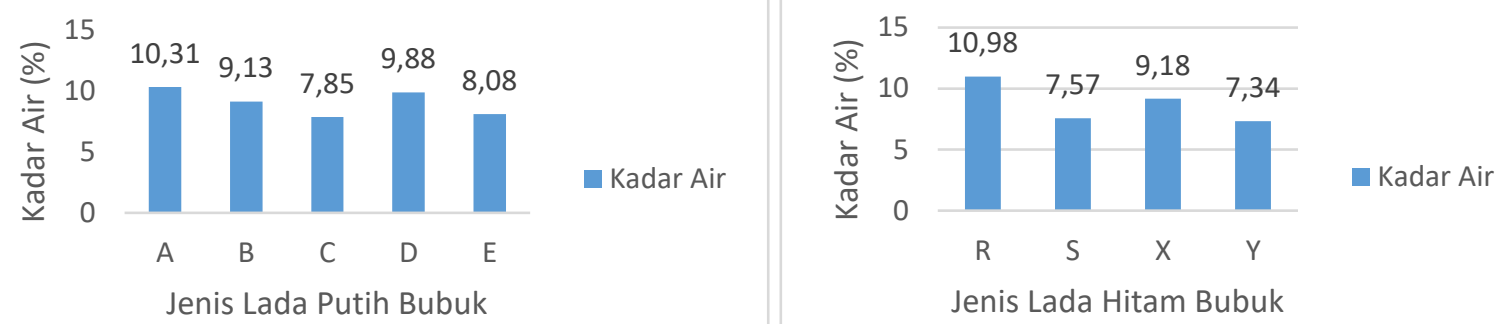

Keterangan : A : Lada putih bubuk dari UKM di Samboja Kabupaten Kutai Kartanegara, B : Lada putih bubuk dari UKM di Kota Bontang, C, D, E : Lada putih bubuk di Pasaran (Samarinda), R : Lada hitam bubuk dari UKM di Samboja Kabupaten Kutai Kartanegara, $S$ : Lada hitam bubuk dari UKM di Kota Bontang, X, Y : Lada hitam bubuk di Pasaran Samarinda

Gambar 1. Kadar Air Jenis Lada putih bubuk, Lada hitam bubuk dari UKM di Kalimantan Timur dan Lada di Pasaran Samarinda

Sembiring dan Hidayat (2012) mengungkapkan factor yang menentukan kadar air suatu produk lada adalah kondisi udara pada proses pengeringan, proses penyimpanan, suhu ruangan, waktu dan bahan lada itu sendiri. Kadar air dalam suatu bahan menurun apabila suhu ruang penyimpanan dan kadar air mengalami kesetimbangan (Risfaheri, 2019). Kesetimbangan dapat terjadi disebabkan oleh adanya laju energi yang masuk dan keluar pada system pengeringan (Suriadi \& Murti, 2012). Hasil kadar air lada pada perlakukan seperti Gambar 1 juga dipengaruhi oleh laju permukaan sangat erat hubungannya dengan laju perpindahan panas bahan dan luas permukaan perpindahan panas dan laju energy yang masuk kedalam bahan yang dikeringkan (Suriadi \& Murti, 2012).

\section{Kadar Piperin Lada putih bubuk dan Lada hitam bubuk Produksi UKM di Samboja, UKM di Bontang dan di Pasaran (Supermarket)}

Bubuk lada putih dan lada hitam dari ukm samboja dan dari pasaran memiliki kadar piperin seperti pada Gambar 2. Kadar piperin lada pada Gambar 2 menunjukkan bahwa kadar piperin lada putih bubuk dan lada hitam bubuk di pasaran Samarinda lebih tinggi dibandingkan dengan lada putih bubuk yang hasilkan dari kedua UKM di Kalimantan Timur. Kandungan kadar piperin lada putih bubuk dari pasaran di Samarinda $(D, E)$ dan lada hitam bubuk dari pasaran Samarinda di atas 6\%. Hasil kadar piperin lada pada sampel lada putih bubuk memenuhi standar SNI 01-3717-1995 dan standar SNI 0004-2013 baik mutu 1 maupun mutu II yaitu mencantumkan nilai hasil pengujian dan juga memenuhi standar mutu lada putih skala internasional yaitu ASTA dan ISO sebesar 4\%.

Berdasarkan Gambar 2 bahwa kadar peperin bubuk lada hitam memenuhi SNI 01-31791992 katagori mutu I dan mutu II (BSN, 1992) dan kategori Mutu I dan Mutu II dengan mencantumkan hasil pengujian sesuai SNI 0005 (BSN, 2013). Kadar piperin lada yang dihasilkan juga memnuhi standar mutu internasional lada hitam seperti ASTA, ESA dan ISO sebesar 4\% (Purwanto \& Balittri, 2011). Dang dan Phan (2014) mengungkapkan bahwa bahan aktif lada yaitu kandungan kadar piperin sebesar $6 \%$, yang digunakan di industri farmasi seperti bahan untuk mengobati batuk, sebagai bahan anti malaria dan bahan anti pembengkakan. 

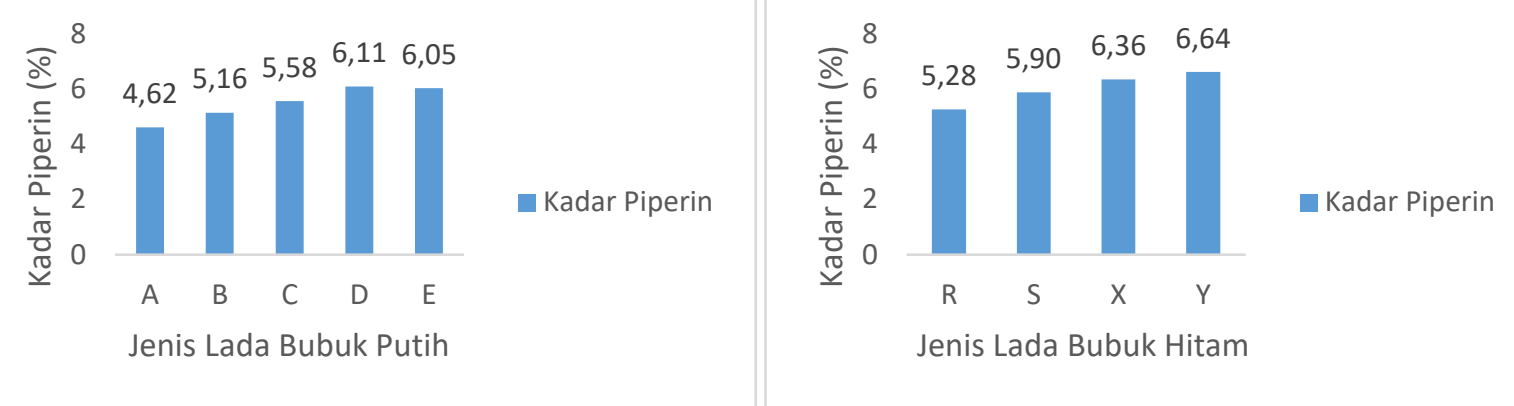

Keterangan : A : Lada putih bubuk dari UKM di Samboja Kabupaten Kutai Kartanegara, B : Lada putih bubuk dari UKM di Kota Bontang, C, D, E : Lada putih bubuk di Pasaran (Supermarket), R : Lada hitam bubuk dari UKM di Samboja Kabupaten Kutai Kartanegara, $S$ : Lada hitam bubuk dari UKM di Kota Bontang, X, Y : Lada hitam bubuk di Pasaran di Samarinda.

Gambar 2. Kadar Piperin Lada putih bubuk, Lada Samarinda hitam bubuk dari UKM di Kalimantan Timur dan Lada di Pasaran

Hilangnya rasa pedas pada lada putih bubuk diakibatkan karena kadar piperin lada putih bubuk lebih rendah dari lada hitam bubuk. Hal ini sama dengan hasil penelitian Menurut (Hikmawanti et al., 2016) kadar piperin pada lada hitam lebih besar dari lada putih. Ini terjadi karena pemanenan lada putih lebih matang dibandingkan dengan lada hitam dan proses pengolahan lada putih sebelum dibuat bubuk dimana lada putih mengalami proses perendaman beberapa hari dengan air mengalir untuk mengeluarkan kulitnya serta proses pengeringan sehingga senyawa chavicin, asam isopiperat dan asam isochavicinat dari daging buah yang merupakan isomer piperin dari turunan piperidida asam tidak jenuh hilang sehingga rasa pedas pada lada putih bubuk tidak sama dengan rasa pedas pada lada hitam dan proses pengeringan (Rachmat, 1991). Selain itu juga terbentuknya asam piperat dan senyawa piperidin mengakibatkan kadar piperin mengalami penurunan sehingga rasa nyengat atau pedas pada lada hlang (Rachmat, 1991).

Kadar piperin lada putih bubuk putih, lada hitam bubuk yang dihasilkan UKM di daerah Samboja dan UKM di Bontang lebih tinggi dibandingkan kadar piperin di daerah Loa Janan, daerah Muara Badak yaitu 3,82 $\pm 1,06 \%$ (lada putih) dan lada hitam (3,18 $\pm 1,06 \%)$, lada Petaling I untuk lada putih $(3,03 \%)$ dan Natar untuk lada hitam $(2,35 \%)$ (Rostiana et al., 2018). Perbedaan kadar piperin yang dihasilkan ini dipengaruhi oleh kematangan suatu buah lada (Rostiana et al., 2018). Lal (2012), genotip atau varietas tanaman dengan tempat interaksi tumbuhnya berpengaruh terhadap kualitas kandungan yang dihasilkan.

Menurut (Thiel et al., 2014) lada hitam menghasil rasa pedas dengan konsentrasi 50$90 \mathrm{gr}$ pieperin/kg lada. Meghwal \& Goswami (2013), "piperine lada hitam tidak hanya menghasilkan rasa pedas, rasa menyengat yang berfungsi sebagai imunomodulator. Antioksidan, anti karsigonetik, anti inflasi, anti maag dan anti amuba".

\section{Kadar Minyak Atsiri Jenis Lada putih bubuk dan Lada hitam bubuk Produksi UKM di Samboja, UKM di Bontang dan di Pasaran (Supermarket)}

Minyak atsiri pada umumnya digunaan dalam industri sebagai penambah flavor pada makanan, sebagai bahan baku farmaka, bahan baku kosmetik dan aromaterapi (Feriyanto et al., 2013). Minyak atsiri dapat ditemukan pada tanaman yang mengandung minyak atsiri. Salah satu tanaman minyak atsiri adalah tanaman lada yaitu lada hitam dan lada putih yang memiliki kandungan minyak atsiri berbeda-beda. 
Minyak atsiri sangat menetukan roma dan rasa pedas pada lada (Chandran \& Goel, 2012). Kadar minyak atsiri jenis lada putih bubuk dan jenis lada hitam bubuk dari ukm di samboja kabupaten kutai kartanegara dan dari pasaran (supermarket) dapat dilihat pada Gambar 3.

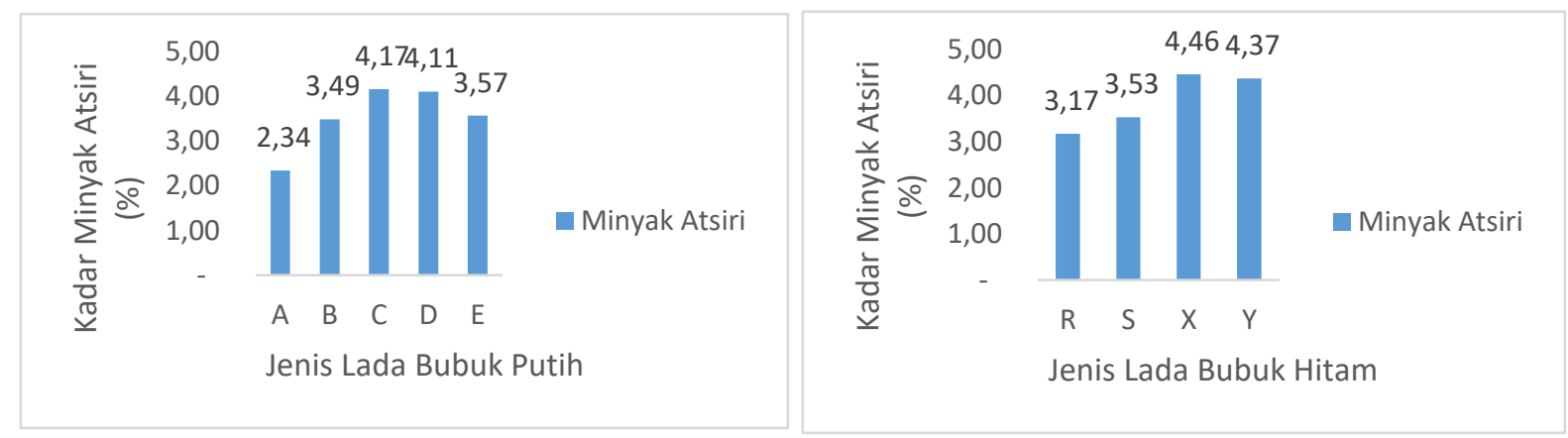

Keterangan:

A : Lada putih bubuk dari UKM di Samboja Kabupaten Kutai Kartanegara, B : Lada putih bubuk dari UKM di Kota Bontang, C, D, E : Lada putih bubuk di Pasaran (Supermarket), R : Lada hitam bubuk dari UKM di Samboja Kabupaten Kutai Kartanegara, S : Lada hitam bubuk dari UKM di Kota Bontang, X, Y : Lada hitam bubuk di Pasaran Samarinda.

Gambar 3. Kadar Minyak Atsiri Jenis Lada putih bubuk dan Lada hitam bubuk Produksi UKM di Samboja, UKM di Bontang dan di Pasaran (Supermarket)

Gambar 3 menunjukkan bahwa nilai kadar minyak atsiri antara lada hitam dan lada putih bubuk terdapat perbedaannya tidak terlalu jauh. Ini terjadi karena penuapan senyawa volatile dalam minyak atsiri. Gambar 3 menunjukkan bahwa kadar minyak atsiri lada putih bubuk dan lada hitam bubuk memenuhi mutu yang dipersyaratkan standar mutu internasional lada putih untuk parameter kadar minyak atsiri: ASTA (American Spice Trade Association) dan ESA sebesar 1,5\%, dan SNI sesuai hasil analisa mutu I dan mutu II. Standar mutu lada hitam untuk parameter kadar minyak atsiri: ASTA, ESA, sebesar 2\% dan ISO sebesar $1 \%$ dan SNI Lada hitam maupun lada hitam bubuk mencamtumkan sesuai hasil penelitian (Purwanto dan Balittri, 2011; Risfaheri, 2019).

Kadar minyak atsiri pada lada baik lada hitam bubuk maupun lada hitam bubuk dapat diperoleh tinggi apabila lada tersebut bebas dari air, dimana kadar air lada putih bubuk dan dan lada hitam bubuk seperti pada Gambar 1. (Rusli, 1996) minyak atsiri dapat diperoleh tinggi ( $\pm 4,96 \%)$ apabila bebas mengandung air.

Selain itu juga waktu penyimpanan, suhu penyimpanan dan kemasan lada sangat mempengaruhi dari minyak atsiri lada putih bubuk dan lada hitam bubuk karena terjadi reaksi oksidasi sehingga menurunkan nilai kadar minyak atasiri dan komponen senyawa kimia (Komponen senyawa kimia dalam minyak atsiri lada putih bubuk dan lada hitam bubuk terdapat senyawa sesquiterpen (a-kariofilen, $\beta$-kariofilen, dan $\beta$-farnesen) merupakan aroma lada (Sembiring \& Hidayat, 2012). Hasil penelitian (Anggraini et al.,2018) menunjukkan bahwa senyawa penyusun utama lada hitam adalah trans-caryophellene $(23,77 \%)$, limonene (18,20\% dan delta-3carene $(13,51 \%)$.

Menurut Liu et al. (2018), kelembaban, minyak esensial lada, monoterpene, piperine dan asam lemak tak jenuh menurun karena adanya teknik penggilingan. Hal ini jelas produk lada putih bubuk dan lada hitam bubuk yang ada di kedua UKM melalui proses penggilingan atau penghancuran hingga menjadi bubuk mengunakan alat penggilingan lada sehingga terjadi penguapan beberapa senyawa esensial lada (minyak atsiri). Lada pada umumnya 
mengandung Komponen senyawa esensial yaitu pinene dan a-terpinene merupakan senyawa yang mudah menguap (Maharaj \& McGaw, 2020). Selain itu juga kondisi, iklim, tanah tumbuh, umur panen, metode yang digunakan dan cara penyimpan minyak atsiri merupakan salah faktor penurunan nilai kadar minyak atsiri dalam suatu tanaman lada (Meika Syahbana Rusli, 2010; Baser dan Buchbauer, 2009). Menurut Milojević et al. (2013) bahwa laju ekstraksi minyak atsiri pada tanaman terjadi pada proses difusi minyak atsiri ke bagian dalam perumukaan yang padat.

\section{KESIMPULAN}

Karakteristik hasil analisis mutu lada putih bubuk dan lada hitam bubuk dari ketiga lokasi pengambilan sampel secara berturut-turut adalah produk lada putih bubuk dengan parameter kadar air: $(10,31 \% ; 9,13 \% ; 7,85 \% ; 9,88 \% ; 8,08 \%)$, kadar piperin: $(4,62 \%$; 5,16\%; 5,58\%; 6,11\%; 6,05\%). Minyak atsiri (2,34\%; 3,49\%; 4,17\%. 4,11\%; 3,57\%). Hasil analisis lada hitam bubuk dengan parameter kadar air: (10,98\%; 7,57\%; 9,18\%; 7,34\%), kadar piperin: $(5,28 \% ; 5,90 \% ; 6,36 \% ; 6,63 \%)$ dan minyak atsiri: $(3,17 \% ; 3,53 \% ; 4,46 \%$; 4,37\%). Hasil analisa lada dari ketiga parameter tersebut memenuhi standar mutu (SNI 013717-1995, SNI 01-3179-1992, SNI 0004:2013, SNI 005:2013) dan standar mutu internasional (ASTA, ESA, IPC, ISO).

\section{DAFTAR PUSTAKA}

Ahmad, N., Fazal, H., Abbasi, B. H., Farooq, S., Ali, M., dan Khan, M. A. 2012. Biological role of Piper nigrum L. (Black pepper): A review. Asian Pacific Journal of Tropical Biomedicine, 2(S), 1945-1953. https://doi.org/10.1016/S2221-1691(12)60524-3

Al-Shahwany, A. W. 2014. Alkaloids and Phenolic Compound Activity of Piper Nigrum against Some Human Pathogenic Bacteria. Biomedicine and Biotechnology, 2(1), 20-28. https://doi.org/10.12691/bb-2-1-4

Anggraini, R., Jayuska, A., dan Alimuddin, A. H. 2018. ISOLASI DAN KARAKTERISASI MINYAK ATSIRI LADA HITAM (Piper nigrum L.) ASAL SAJINGAN KALIMANTAN BARAT. Jurnal Kimia Khatulistiwa, 74$), 124-133$.

BPS (Badan Pusat Statistik). 2019. Luas Areal Tanaman Perkebunan Rakyat Menurut Jenis Tanaman (Ribu Hektar), 2017-2019. https://www.bps.go.id/indicator/54/770/1/luasareal-tanaman-perkebunan-rakyat-menurut-jenis-tanaman.html.

Baser, K. H. C., dan Buchbauer, G. 2009. Handbook of Essential Oils Science, Technology, and Applications. CRC Press.

BSN (Badan Standar Nasional). 1995. Standar Nasional Indonesia (SNI) Nomor 01-3717-1995 Lada Putih Bubuk. Badan Standardisasi Indonesia.

BSN (Badan Standar Nasional). 1992a. Sni 01-2891-1992. In Standar Nasional Indonesia: Cara Uji Makanan dan Minuman.

BSN (Badan Standar Nasional). 1992b. SNI 01-3179-1992 Lada Hitam Bubuk. Badan Standardisasi Indonesia.

BSN (Badan Standar Nasional). 2013. SNI 0004:2013 Tentang Lada Putih (p. 27). www.bsn.go,id

Chandran, B., dan Goel, A. 2012. A randomized, pilot study to assess the efficacy and safety of curcumin in patients with active rheumatoid arthritis. Phytotherapy Research, 26(11), 1719-1725. https://doi.org/10.1002/ptr.4639

Dang, Q. T., dan Phan, N. N. 2014. Optimization of supercritical CO2 extraction of oleoresin from black pepper (Piper nigrum L.) and antioxidant capacity of the oleoresin. International Food Research Journal, 21(4), 1489-1493.

DepkesRI. 2010. Materia Medika Indonesia (IV).

Dwivedi, R., Nothaft, H., Garber, J., Xin Kin, L., Stahl, M., Flint, A., van Vliet, A. H. M., Stintzi, 
A., dan Szymanski, C. M. 2016. L-fucose influences chemotaxis and biofilm formation in Campylobacter jejuni. Molecular Microbiology, 101(4), 575-589. https://doi.org/10.1111/mmi.13409

Feriyanto, Y. E., Sipahutar, P. J., Mahfud, dan Prihatini, P. 2013. Menggunakan Metode Distilasi Uap dan Air dengan Pemanasan Microwave. Jurnal Teknik POMITS, 2(1), 93-97.

Gorgani, L., Mohammadi, M., Najafpour, G. D., dan Nikzad, M. 2017. Piperine-The Bioactive Compound of Black Pepper: From Isolation to Medicinal Formulations. Comprehensive Reviews in Food Science and Food Safety, 16(1), 124-140. https://doi.org/10.1111/15414337.12246

Hikmawanti, N. P. E., Hariyanti, Aulia, C., dan Viransa, V. P. 2016. KANDUNGAN PIPERIN DALAM EKSTRAK BUAH LADA HITAM DAN BUAH LADA PUTIH (Piper nigrum L.) YANG DIEKSTRAKSI DENGAN VARIASI KONSENTRASI ETANOL MENGGUNAKAN METODE KLTDENSITOMETRI. Media Farmasi, 13(2), 173-185. https://doi.org/10.12928/mf.v13i2.7769

ISO, 959. 1998. Papper (Piper nigrum L.), Whole or Groudn-Specification-Part 1: Black peper. Kadam, P. V, Yadav, K. N., Patel, F. A., Karjikar, F. A., dan Patil, M. J. 2013. Pharmacognostic, Phytochemical and Physicochemical Studies of Piper Nigrum Linn. Fruit (Piperaceae). International Research Journal of Pharmacy, 4(5), 189-193. https://doi.org/10.7897/2230-8407.04538

Kemendag, R.I. 2019. Siaran pers. Biro Hubungan Masyarakat Kemenperian Perdagangan Republik Indonesia, 1-2. https://www.bi.go.id/id/ruang-media/siaranpers/pages/sp_165814.aspx

Kolhe, S. R., Borole, P., dan Patel, U. 2011. Extraction and evaluation of piperine from piper nigrum linn. International Journal of Applied Biology and Pharmaceutical Technology, 2(2), 144-149. www.ijabpt.com

Kumar, A., Singh, P. K., Parihar, R., Dwivedi, V., Lakhotia, S. C., dan Ganesh, S. 2014. Decreased O-linked GlcNAcylation protects from cytotoxicity mediated by huntingtin exon1 protein fragment. Journal of Biological Chemistry, 289(19), 13543-13553. https://doi.org/10.1074/jbc.M114.553321

Lal, R. K. 2012. Stability for oil yield and variety recommendations' using AMMI (additive main effects and multiplicative interactions) model in Lemongrass (Cymbopogon species). Industrial Crops and Products, 40(1), 296-301. https://doi.org/10.1016/j.indcrop.2012.03.022

Liu, H., Zheng, J., Liu, P., dan Zeng, F. 2018. Pulverizing processes affect the chemical quality and thermal property of black, white, and green pepper (Piper nigrum L.). Journal of Food Science and Technology, 55(6), 2130-2142. https://doi.org/10.1007/s13197-018-3128-8

Loo, T. 1987. Ikhtisar Ringkas dari Dasar-Dasar Farmakognos. Bunda Karya.

Maharaj, S., dan McGaw, D. 2020. Mathematical model for the removal of essential oil constituents during steam distillation extraction. Processes, 8(4), 1-13. https://doi.org/10.3390/PR8040400

Meghwal, M., dan Goswami, T. K. 2013. Piper nigrum and piperine: An update. Phytotherapy Research, 278), 1121-1130. https://doi.org/10.1002/ptr.4972

Meika Syahbana Rusli. 2010. Sukses Memproduksi Minyak Atsiri. AgroMedia.

Milojević, S. Ž., Radosavljević, D. B., Pavićević, V. P., Pejanović, S., dan Veljković, V. B. 2013. Modelovanje kinetike hidrodestilacije etarskog ulja iz biljnih materijala. Hemijska Industrija, 675), 843-859. https://doi.org/10.2298/HEMIND121026009M

Nahak, G., dan Sahu, R. K. 2011. Phytochemical evaluation and antioxidant activity of Piper cubeba and Piper nigrum. Journal of Applied Pharmaceutical Science, 01(08), 153-157.

Pundir, R. K., dan Jain, P. 2010. Volume: I : Issue-2 : Aug-Oct -2010 COMPARATIVE STUDIES ON THE ANTIMICROBIAL ACTIVITY OF BLACK PEPPER ( PIPER NIGRUM ) AND 
TURMERIC ( CURCUMA LONGA ) EXTRACTS Lecturer in Biotechnology, Kurukshetra Institute of Technology \& Management, Bhor Lecturer in. International Journal of Applied Biology and Pharmaceutical Tecnology, 1(2 Aug-Oct), 492-501.

Purwanto, E. H., dan Balittri. 2011. Harmonisasi Standar Lada Indonesia Spesifikasi yang diminta oleh Negara Konsumen. Warta Penelitian Dan Pengembangan Tanaman Industritian Dan Pengembangan Tanaman Industri, 173 Desember), 27-31.

Rachmat, E. 1991. Kajian Perubahan Karakteristik Mutu lada Hijau Kering (Dehydrated Green Pepper) dengan variasi penambahan asam sorbated $C A M$ pengeringan. Institut Pertanian Bogor.

Risfaheri. 2012. Diversivikasi Produk Lada(Piper Nigrum) Untuk Peningkatan Nilai Tambah. Buletin Teknologi Pascananen Pertanian, 8(1), 15-26.

Risfaheri. 2019. Masalah dan Standar Mutu LAda, Monograf Tanaman Lada. In Jurnal Sains Farmasi \& Klinis (Vol. 6, Issue 2). https://doi.org/10.25077/jsfk.6.2.180-185.2019

Rostiana, O., Manohara, D., dan Ruhnayat, A. 2018. KARAKTERISTIK PRODUKSI DAN MUTU LADA LOKAL KALIMANTAN TIMUR Characteristics of Production and Quality of East Kalimantan B lack Pepper. 28(2), 113-126.

Rusli, S. 1996. Pengolahan dan penyimpanan lada. Monograf Tanaman Lada No. 1. Balai Penelitian Tanaman Rempah dan Obat.

Sabina, E. P., Nasreen, A., Vedi, M., dan Rasool, M. 2013. Analgesic, Antipyretic and Ulcerogenic Effects of Piperine: An Active Ingredient of Pepper. Journal of Pharmaceutical Sciences and Research, 5(10), 203-206.

Sembiring, B. S., dan Hidayat, T. 2012. Perubahan Mutu Lada Hijau Kering Selama Penyimpanan Pada Tiga Macam Kmasan dan Tingkat Suhu. Jurnal Littri, 18 (3)(September), 115-124.

Suriadi, I. G. A. K., dan Murti, M. R. 2012. Kesetimbangan Energi Termal Dan Efisiensi Transient Pengering Aliran Alami Memanfaatkan Kombinasi Dua Energi. Jurnal Teknik Industri, 12(1 Februari), 34-40. https://doi.org/10.22219/jtiumm.vol12.no1.34-40

Thiel, A., Buskens, C., Woehrle, T., Etheve, S., Schoenmakers, A., Fehr, M., dan Beilstein, P. 2014. Black pepper constituent piperine: Genotoxicity studies in vitro and in vivo. Food and Chemical Toxicology, 66, 350-357. https://doi.org/10.1016/j.fct.2014.01.056

Timur, D. P. P. K. 2019. Lada. https://disbun.kaltimprov.go.id/artikel/lada

Vasavirama, K., dan Upender, M. 2014. Piperine: A valuable alkaloid from piper species. International Journal of Pharmacy and Pharmaceutical Sciences, 6(4), 34-38.

Zarai, Z., Boujelbene, E., Ben Salem, N., Gargouri, Y., dan Sayari, A. 2013. Antioxidant and antimicrobial activities of various solvent extracts, piperine and piperic acid from Piper nigrum. LWT - Food Science and Technology, 50(2), 634-641. https://doi.org/10.1016/j.Iwt.2012.07.036 